\title{
Metaphorical Words and Expressions: Film Review Based on the Dialogue in Puteri Gunung Ledang (The Princess of Mount Ledang)
}

\author{
Sharipah Nur Mursalina Syed Azmy ${ }^{1}$ \\ ${ }^{1}$ Department of Modern Language and Communication, Faculty of Language and Communication, Universiti \\ Sultan Zainal Abidin, Kuala Nerus, Terengganu, Malaysia \\ Correspondence: Sharipah Nur Mursalina Syed Azmy, Department of Modern Language and Communication, \\ Faculty of Language and Communication, Universiti Sultan Zainal Abidin, Kuala Nerus, Terengganu, Malaysia. \\ E-mail: shnurmursalina@unisza.edu.my
}

\author{
Received: June 12, 2017 Accepted: July 10, 2017 Online Published: October 11, 2017 \\ doi:10.5539/ijel.v7n6p221 URL: http://doi.org/10.5539/ijel.v7n6p221
}

\begin{abstract}
This paper discusses the use of words and expressions in the metaphorical dialogues used in the film Puteri Gunung Ledang (PGL). The Malays are known for their gentle and amiable characters. These features include the way they speak. This can be observed when they covertly deliver messages in a conversation. The habit of not being straightforward and subtly conveying message are nurtured since a very young age. This act is regarded as a way of being courteous and practiced among themselves or others while communicating. As the result, the Malays often use metaphor in communication to make comparison on matters or things, covertly. Such comparison led to the use of different words comparing other things. Since the life of the Malays is heavily connected to their natural environment, they tend to interpret these elements in their daily use of language. In addition, this study has discovered that the Malays are really close with their natural environment. These relationships were expressed through the use of figurative language with words and phrases that are environment-oriented. The use of words oriented by anatomy, natural environment, flora and fauna, behaviour, jewellery and food is distributed as metaphor in PGL movie. These are the elements related to the natural human environment. In fact, due to this close connection, it was found that the Malays feel comfortable to relate these elements with nature and human behaviour in life.
\end{abstract}

Keywords: metaphor, thoughts, anatomy, nature, flora and fauna

\section{Introduction}

Kiasan or figurative word or phrase in English is used as a metaphor to create the impression for a statement or description (Dictionary of Linguistics, 1997, p. 31). The term 'figurative' is derived from the English term, which means deviation in terms of meaning or the position from the ones commonly used. Its objective is to create a special meaning or effect. The form includes rhetorical style, figurative style, expressions, idioms, similes and allusions. Meanwhile, the forms of expression are considered to be deviated from the common usage (Mas, 1988, p. 153).

Figurative language has multiple meanings. The extension of the meaning figuratively happens by taking one or more elements from the meaning of a word and applied them to other objects that were not originally positioned in the original meaning of the word. The meaning elements taken may consist of shapes, psychological characteristics, connectivity and a part of it or similarity in functions. Furthermore, meanings are built based on several similarities between the original meaning of word with other associated objects and some comparable similarities (Muhammad, 1987, p. 65).

On the other hand, metaphor is a word that possesses meaning behind another word. It is often used to describe something by comparison to other matters or things subtly or indirectly delivered. Thus, a figurative message can be delivered effectively and efficiently without offending others. Vocabulary knowledge is fundamental to effective communication (Nation, 2001). Usually, a metaphor or figurative is established by the members of community based on the attributes or characteristics that are considered to be most prominent in something. These elements are often adopted from the closest element or that usually seen in life. 


\section{Figurative Words and Expressions in the PGL Film Dialogue}

The philosophy, which underlines the thinking of the Malays, are produced through observation, appreciation of religion, reason, tradition and culture, as well as nature that include flora, fauna, nature, life and environment that foregrounds their lives (Hamzah \& Mat Hassan, 2011, p. 34), thus resulting in the production of such thoughts. This study found that there are different types of word and expression used in the metaphor dialogue of PGL movie, which comprised the figurative elements of anatomy, natural environment, flora and fauna, behaviour, jewellery and food.

\subsection{Anatomy-Oriented Metaphorical Words and Phrases}

Anatomy is the study or knowledge of the living body constructions such as humans, animals and plants (Kamus Dewan, 2005, p. 52). Human anatomy is made up of parts with description and function of each based on human characteristics associated with a particular body part (Omar, 2008, p. 160). Anatomical metaphor word is a word characterising the human body associated with human nature in the form of metaphor. This study discovered that there are some elements of anatomy used in the PGL movie dialogue such as the tongue, heart, head, face, bile, hair, chest, arms, legs, tears, blood and body.

Anatomical metaphor was utilised in this study to show a connection between human nature with certain body parts. For instance, the word "heart" was used to describe the feeling, emotion and attitude of a person described in the form of idioms, kata hati (conscience) and harapan hati (expectation). Moreover, happiness and joy were represented by parable besar hati (delighted) However, sadness was reflected in parable including bagai racun menusuk kalbu (affliction) and yang tinggal hati tak elok, yang pergi hati tak senang (agony of mind), which bring the same notion namely heartache. This is because from the worldview of the Malays, heart is an important organ that acts as a symbol of unity for the body structure. So, the heart plays a big role in determining an individual's characters and behaviours. World view of the Malays regarding heart is related to Islam, which considers the heart as the pulse of the whole human life. Thus, the acceptance and rejection of any information or events are decided by the heart (Omar, 1996).

Additionally, the use of the word face is a metaphor for a person's dignity, which was reflected in expressions such as seperti menconteng arang di muka sendiri (shamefaced) referred to as bringing disgrace in reputation. Furthermore, face is a part of the anatomy that is often seen and used to identify a person. Hence, the face brings a sense of attitude or the dignity appropriate to its function as part of the body to be recognised. On the other hand, the tongue is used to describe someone's manner of speaking. For instance, the idiom lidah bercabang (manipulative) and hyperbole terlalu tajam (offensive when speaking) dan biadap lidahmu (insolent) bring similar meaning; hypocrite and rude. It describes one's attitude as not keeping promises and not courteous when communicating. Generally, it is known that the tongue is used as a tool of conversation (Kamus Dewan, 2005, p. 937). Hence, one cannot speak properly without tongue.

In addition, it is known that the use of arms and legs of human life has something to do with act. Therefore, the use of the word hands and feet in the hyperbole tangan terikat di langit, kaki terpasak di bumi (the state of hopelessness) portrays Hang Tuah's inability to do something. However, most metaphors used for hands and feet was displayed to describe the kinds of negative activity such as panjang tangan (thief), kaki judi (gambler) and kaki botol (drunkard) (Omar, 2015, p. 161).

On the other hand, the reflection of sadness was expressed in berendam air mata (woe). The existence of compatibility of tears of grief in human life produces a highly efficient interpretation since every grief is shown with tears.

The body is used to describe difficulties and feelings of unparalleled love. Generally, the body is an existing torso (Kamus Dewan, 2005, p. 612). Meanwhile, the difficulty was described by the analogous body expression jasad tidak setanding mimpi (facing something beyond one's ability).

The reflection of difficulty was seen in body strength to face something since the body has the ability to face something on its own and associated with the expression berdiri sama tinggi, duduk sama rendah (of the same level), which represents the rank in life. This was associated with the difficulty of Hang Tuah to be with Gusti Putri (Princess of Mount Ledang) due to the difference in their status. The illustration of incomparable feeling of love was reflected in the analogous expression of melepasi jasad ini (crossing one's limit), which was described by the word body representing a substantial part of the human body.

Even so, the physiological elements represented by the blood have been widely used especially in producing metaphorical implicature (Omar, 2015, p. 160). Blood is essential to all living organisms since it serves to distribute oxygen throughout the body of respiratory system. In addition, blood acts to defend the body from 
infection. These have made blood to be considered as a symbol of kinship or consanguinity, which has to do with ancestry and not through marriage. The word blood was used in PGL movie dialogue describing family ties that exist between father and son by the expression darah seguntang tetap mengalir (blood is thicker than water).

Moreover, the word blood is widely used as a metaphor to describe the degree and concrete objects that present in the world. In fact, the engagement terms of Mount Ledang Princess consist of blood figurative words such as darah putih (white blood), darah kuning (yellow blood), darah merah (red blood) and blood darah seguntang tetap mengalir (blood is thicker than water). Blood flow in the human body shows the closeness of these elements in life, causing the word blood to be used to describe other living creatures that exist in the world. Meanwhile, concrete object that is analogous to blood is the bridge; the link between the two places. Determination to resist opponents is also analogous with blood in titik darah penghabisan (until the last drop of blood).

\subsection{Nature-Oriented Metaphorical Words and Phrases}

Nature is referred to the world, continents, world champion, rat, earth, cloud, creation (Kamus Besar Bahasa Melayu Utusan, 1995, p. 36). The natural environment is made up of things related to the natural environment in either physical forms such as temperature, climate, humidity, wind, the intensity of the sun, the body of water (depth, rain water, river currents, waves, sea, lakes and the like) and topography or chemical forms including gases, nutrients, acidity, mineral salts and salinity (Ramlan, 1999). The experience suffered by the Malay community in an ongoing basis with the natural environment created a strong bond between them. Indirectly, the birth of the Malays' thinking is characterised based on the natural environment like the moon, the earth, the light of the sun, soil, air, sea, mountain, wind, ocean, universe, water, stone, cloud, peak Ledang (Mount Ledang), eclipse, twilight and the sky.

This reflects the nature-based thinking of the Malay community. The word mountain in this study was described as a very promising dream to be achieved despite obstacles such as in harapan yang menggunung tinggi (mountain-high hope) and mengharapkan cinta yang menggunung (expecting great love). In addition, the word described the challenges or hardships in life in analogous expressions like merentas samudera membelah gunung (crossing the ocean, defeating the mountains) and demi cinta, tiada gunung terlalu tinggi (no mountains are too high for love).

Meanwhile, the expressions of freedom, togetherness, relief and the conveying of information are analogous with the words of wind or air. The nature of the wind or air that is free to move without any obstacle was reflected through kuat hembusan angin (strong wind blow). This illustrated the message or information related to things people talk about. This situation further reflects the freedom of human to speak or communicate with something in the community. Additionally, the feeling of relief and yearning were expressed in kini kurasa deruan angin menusuk dada (I can feel the breeze in my chest), which is connected with heart's reassurance when you can meet with your loved ones. The expression bernafas pada udara yang sama (breathing the same air) reflects unity in life, whereas air reflects the condition of being in the same place.

Environmental factors experienced by the Malay community with the ocean such as getting foods and the main communication system encourages the use of symbols of sea in figurative language. The sea reflects the challenges in life that are analogous to the expressions jangan berangan meniti laut (do not dream of crossing the ocean). The ocean covers $2 / 3$ of the earth, while the mainland only covers $1 / 3$ of the earth. The nature of the sea that is always choppy and turbulent symbolises significant challenges to be faced crossing the ocean.

In addition, the weakness and futile efforts can be interpreted with the word water. The disadvantage against someone for something was reflected in the expression jangan berangan meniti laut, takut air menjadi api (do not dream of crossing the ocean, for the water might turn to fire) from this study. Air is a fluid element that can be of various forms while water has no form of its own. It is used in the interpretation of human behaviours that are not strong enough to deal with a case of difficulty and constant change. Moreover, the insignificant effort was expressed in the expression air setempayan diceduk segayong, dapatkah siram api di gunung (one should know their limits) that shows the power of lower classes that are unable to compete with the elite.

Furthermore, the word "api" (fire) was used in the same expression. The nature of fire was reflected with difficulty and power in takut air menjadi api (for the water might turn to fire) and api di gunung (fire in the mountain). The nature of fire that is hot and difficult to control when burning can be interpreted as human nature in the face of difficulties. The nature of power with the leaders is analogous to a figurative fire as the demand of the head that is hard to be opposed by the lower class people.

To bring a deeper emotional impact in describing the greatness of love and longing, the moon and the earth were 
used in expressions ungkapan umpama rindu bulan mengelilingi bumi (like the moon missing the earth). Undoubtedly, the moon and the earth are interdependent with each other in the nature of celestial event. Moon is a natural satellite that moves around the earth and give light to the earth during the night. The need for each other leads to a great relationship. The moon and the earth symbolisation is a symbol of the couple, the men and women needing each other.

The loyalty in a relationship is analogous to the expression menginjak pada tanah yang sama (standing on the same ground). Loyalty between lovers can be seen from the word land, which is part of the Earth's surface with boundaries. The desire to live together in a close to the border indicates a high degree of loyalty between lovers.

Stone is a natural object or cosmology realised in God's creation. It is a solid non-metallic minerals that are not burned, not malleable and do not disintegrate in water. This property is analogous to the expression biar beribu tahun air mengukir batu (let the water carves the stones in thousands of years) reflecting the obedience of subordinates toward their chief. Moreover, the attitudes of not easily affected, not easily trust outsiders and not easily follow without first investigating showed boundless devotion to his own head. In fact, to create a very deep feelings and unrivalled to love, figurative words of maya and peak Ledang were used. The passion to love someone is analogue in the expression of cinta dinda seagung maya (My love is as great as the universe) and cinta kanda melepasi puncak Ledang ini, melepasi jasad ini (My love is beyond this body and the Mount Ledang).

In addition, the grief experienced by Tun Teja and Gusti Putri are analogous to the word eclipse. Eclipse is basically divided into two, namely solar and lunar eclipses. The occurrence of the eclipse causes the earth to be in the dark and dismal period of time. The darkness that occurs will affect the daily lives of human. The provisions of the darkness can cause distress in human life as interpreted in the conversation between Tun Teja with Gusti Putri.

Likewise, a figurative of dusk is the beginning of dark in the evening that usually displays bright and blue sky for a few moments after the sunset. This event shows the end of the afternoon followed by the evening. The word dusk in the PGL movie dialogue reflected the increasing age through the expression menjengah senja (dusk is coming). It is the increasing age from young to old that is analogous to atmosphere that will fade into night. Meanwhile, the brief movement stage from evening to night and from young to old is analogous to the dusk figurative.

\subsection{Flora and Fauna-Oriented Metaphorical Words and Phrases}

Flora is the overall plants in a province (Kamus Dewan, 2005, p. 413), while the fauna is all animals that live in a particular province (Kamus Dewan, 2005, p. 208). Many years ago, the life of the Malays was surrounded by the flora and fauna. They plant crops and raise animals. Their residence and needs with food source are derived from flora and fauna around them (Karim, 2000, p. 19). So, it is not surprising that many elements of the flora and fauna are used as a metaphor in the PGL film dialogue. Among them were inspired by flora and fauna and were used in the movie dialogues such as jasmine flowers, roots, buffalo, chickens, ferrets, birds Kedidi, Raja Wali, hawks and pigeons.

The existence of a close relationship between the Malays and the environment makes them use a lot of flora and fauna to interpret something. It has been agreed by Ismail $(1985$, p. 37) that the Malays are known to live in the jungle and open space along the river and coast. The greenery of the jungle, orchards, valleys and beaches bring them closer to the natural forms of their own. Since the Malays are concerned with elements of flora and fauna around them, the common usage of them can be seen as the main background in the production of pantun (pantoum) as the clue or meaning in it. The brief of misery is very intelligently analogous in macam kerbau hidup dikasi (like buffalo castrated). Buffalo is a strong animal and often maintained by farmers in ancient times since they were used for ploughing. Thus, the nature of masculinity and strength of a buffalo would disappear if it is sterilised, which causes misery in life.

Other than that, the idea of power is depicted by eagle with such expression in a hint of poetry, which is disambar helang bukan merpati (stricken by eagle, not pigeon). Generally known, the eagle is a bird of prey with power and is feared by other animals compared to the pigeon, which is a type of domesticated bird and preferably humans. So, it is not surprising if something will be first struck by the eagle and not the pigeon. Due to this difference in nature, eagle is known for its strength. At the same time, pigeon is known as the symbol of gentleness and weakness as in the proverb jinak-jinak merpati (shy) Jasmine was chosen as a hint in the poem (pantoum) because it is known amongst the Malays as something beautiful, white in nature with a long lifespan. This beauty gravitates beetles, bees, birds and various wildlife attracted to honey. The nature jasmine flower is analogous with drugs sold by drug dealers in the PGL film. 
Moreover, the nature of chicken that is always pawing the ground to look for food was analogised with metaphorical expression pura-pura mencari ayam (deceitful). This trait describes the one who is pretentious; hiding his true, bad intention while doing something else. Even so, the word chicken can be contextualised in few manners in PGL movie dialogue. Its use also showed differences in strength compared to the figurative word of fox. The reflection of power among men has been long described with the figurative fox, which is a kind of wild animals living in the forest. This was analogous to the interpretation of the expression masakan ayam boleh selari musang!! (the chicken is nothing like fox) The difference in strength between the fox and the chicken is very significant as chicken is a typical poultry but not as agile as fox.

However, the word "Raja Wali" in the phrase jika patah sayap Raja Wali, bertongkat jua (Wali (bird) is not going to give up even the wings are broken) reflects Hang Tuah's determination to face difficulty. In accordance with the habits of the birds to travel from one place to another, this symbolises that human had to deal with difficulties before heading to a place. Kedidi bird symbolised the willingness of Gusti Putri who puts aside her reputation to get something. Although the bird is small and not as strong as the eagle, its willingness to do something is greatly appreciated in the expression sekecil burung Kedidi, mengharapkan cinta yang menggunung (Kedidi (bird) is small in size yet having high hope for great love). Despite her small size, she is willing to put aside her dignity as a daughter of the king to accept the love of a commoner; Hang Tuah.

\subsection{Behaviour-Oriented Metaphorical Words and Phrases}

Behaviour is recognised through act or conduct. It is something that is done by organism (Mohamed, 1990, p. 131). The close connections between the human behaviours can be clearly seen as every movement they make is their everyday behaviour towards the environment. As a result, a lot of people use behaviour in manipulating language and consequently, language that carries multiple meanings is produced. Figurative language in the PGL movie dialogue used a lot of behaviour-oriented figurative words to reflect anger, longing, agreements, life, frustration, anger, joy and obedience. Among the figurative elements used for behaviour are interfering, uphold, crawl, fly, bound, obedient, doodling and chopped.

Uphold is used to illustrate loyalty. Junjung kasih (upholding love) is an expression amongst the Royal. Therefore, its use involved the upper classes, namely the Sultan with the lower class. The use of this word represents how respectful and obedient is the servant towards the king's edict. The interpretation of anger is analogous with the word mince in the phrase sudah kucincang kau (act of destroying someone). Mince is usually associated with slicing or chopping, slashing the small or fine-grained with a machete or knife. The word chopped in the PGL movie dialogue showed uncontrolled anger until one is willing to kill.

The figurative word of bound is interpreted as a metaphor of the relationship between Hang Tuah and Gusti Putri that is inseparable as in the expression kita sudah saling terikat jika adat menyucikan kaki ini kita lakukan (we are bonded) . Bonded relationship means a relationship that has been subjected between two individuals. Through the element of behaviour, a sense of life was also used in wedding dowry demand made by Puteri Gunung Ledang to describe mosquitoes and germ. This picture is analogous in merangkak bebas (free to move) for germ and terbang bebas di udara (free to move) for mosquitoes. The act or movement to the nature of the mosquito and germ was used to describe life in the metaphor used.

\subsection{Jewellery-Oriented Metaphorical Words and Phrases}

Jewellery is often associated with women due to their nature to love beauty. Thus, the necessity of wearing jewellery is seen as a blessing and grace of Allah S.W.T to his servants (Dakir, 2000, p. 98). However, in the interpretation of the jewellery elements such as pearls and beads, different meanings were carried from their literal definition. This is because the use of pearls and beads symbol in figurative language can carry a variety of connotations.

Figurative words of pearls and beads used as a metaphor in the PGL film dialogue reflect a significant comparison between royalty and commoner. Pearl is a round and hard object produced by oysters. The production of pearl requires a long time with a very high value compared to beads that are only made of glass. This property is analogous to the human being with a variety of status and ethnicity. This trait is illustrated by the gems that are more valuable and highly valuable to interpret the position and strength as well as the power of the elite versus the lower class. The commoner was analogised as beads that are not as standard as pearls, which represent the royals.

\subsection{Food-Oriented Metaphorical Words and Phrases}

Food refers to anything that can be eaten including bread, rice and others (Kamus Dewan, 2005, p. 981). The relationship between food and life of the Malays is very close until today. In addition, food is not only meant to 
be eaten, but is also used as a dowry in marriage or engagement in traditional Malay society. Therefore, food is a very important element in the life of the community and all life on Earth since it is needed for survival. Its substantial importance has led the Malays to choose it as analogous to the life of the community through figurative language.

Since long time ago, the traditional Malay community is known for their agricultural community especially in paddy planting activity to make rice. Rice is one of cereal crops produced by the Malays. It is the staple food ever since. Every day, the Malays consume rice as the main ingredient in their daily menu along with tasty side dishes and curry-based dressings. As the result, a close bond between the rice and dressing was produced and expressed in the expression tak ke mana tumpahnya kuah kalau tak ke nasi (symbolic connection of the rice and gravy; Inseparable).

In addition, the flour is also very close to the life of the Malays. This is because most traditional foods are made of flour including banana cake. This close relationship has led the Malays to manipulate language using the word flour in the proverb rambut yang ditarik, tepung tidak berselerak (act wisely). The fineness of the flour that is easily dispersed by the wind blow requires it to be handled in caution. It is interpreted that human life must be wise in dealing with problems so that the problem can be solved without causing any negative implications.

Additionally, the oil figurative word was also used as a metaphor in the PGL film dialogue. The nature of oil that cannot be mixed with water needs intensive care so that it can be used in good condition. Thus, great care is needed to get something good. Accordingly, oil is used as a metaphor for child. Therefore, a child who is loved can be regarded as ditatang bagai minyak yang penuh (giving full attention), meaning that each family member will ensure and maintain the child's safety.

\section{Conclusion}

Through this study, it can be clearly seen that there is a close relationship between the Malay community and the natural environment. These relationships are expressed through the use of figurative language that uses words and phrases that are environment- oriented. Circle of life in the community close to their natural environment makes it easy to associate these elements with nature and human behaviour in life. This clearly shows the vehicle of their thoughts and insights about life based on natural events and experiences that continuously occur in their everyday life. Thus, the way they think, understand and respond to the situation indirectly reflects the worldview of the Malays. Thoughts and reactions are further applied in the form of speech and reflect the wisdom of native speakers in the content. Thus, the uniqueness of the thinking and ingenuity in a community can be significantly seen as they can interpret everything in the environment in the form of metaphor. Therefore, there is no limit in things or matters for the Malay community to be used in their forms of speech. Any objects or things in the environment in accordance with the treatment and the nature of man can be used in communication implicatures.

\section{References}

Awang, H. (1987). Glosori Mini Kesusasteraan. Petaling Jaya: Fajar Bakti Sdn. Bhd.

Bagea, I. (2010). Metafora dalam Bidang Pertanian Padi Masyarakat Dayak Buket Kabupaten Kutai Barat Kalimantan Timur (Suatu Tinjauan Linguistik Antropologi). Jurnal Humaniora, 22, 43-51. https://doi.org/10.22146/jh.v22i1.984.

Dakir, J. (2000). Pakaian dan Perhiasan Wanita mengikut Perspektif Islam. Kuala Terengganu: Yayasan Islam Terengganu.

Hamzah, Z. A. Z., \& Mat Hassan, A. F. (2011). Bahasa dan pemikiran dalam peribahasa Melayu. GEMA: Online Journal of Language Studies, 11(3), 31-51.

Ismail, S. Z. (1985). Reka Bentuk Kraftangan Melayu Tradisi. Kuala Lumpur: Dewan Bahasa dan Pustaka.

Kamus Bahasa Melayu Klasik. (1997). Kuala Lumpur: Berita Pub.

Kamus Bahasa Melayu. (2008). Selangor: Crescent News (K.L) Sdn. Bhd.

Kamus Besar Bahasa Indonesia (Edisi Kedua). (1997). Departmen Pendidikan dan Kebudayaan: Balai Pustaka.

Kamus Besar Bahasa Melayu Utusan. (1995). Kuala Lumpur: Utusan Publications \& Distributors Sdn. Bhd.

Kamus Dewan (Edisi Empat). (2005). Kuala Lumpur: Dewan Bahasa dan Pustaka.

Kamus Linguistik. (1997). Kuala Lumpur: Dewan Bahasa dan Pustaka.

Karim, N. S. (2000). Unsur Flora dan Fauna dalam Pemikiran Orang Melayu: Satu Tinjauan dari Sudut Pengungkapan. Bahasa Melayu dalam Dekad 90-an. Kuala Lumpur: Akademi Pengajian Melayu. 
Liwoso, M. (2012). Pemahaman Terhadap Metafora Sebagai Sumber Kearifan Masyarakat. Jurnal Kajian Bahasa RANAH, 1(2). http://dx.doi.org/10.14203/rnh.v1i2.19

Mansor, M. M., \& Ishak, N. S. (2011). Peribahasa: Gambaran Minda Melayu dalam Penciptaan Iklan. In: Seminar Antarabangsa Linguistik dan Pembudayaan Melayu, VII(SALPBMVII), 9-10 Nov 2011, UPM.

Maros, M. (2011). Strategi Kesantunan Melayu dalam Membuat Teguran. Jurnal Elektronik Jabatan Bahasa \& Kebudayaan Melayu, 3, 7-20.

Mas, K. (1988). Perbincangan Gaya Bahasa Sastera. Kuala Lumpur: Dewan Bahasa dan Pustaka.

Mohamed, M. N. (1990). Pengantar Psikologi: Satu Pengenalan Asas kepada Jiwa dan Tingkah Laku Manusia. Kuala Lumpur: Dewan Bahasa dan Pustaka \& Kementerian Pendidikan Malaysia.

Muhammad, A. (1987). Analisis Semantik Ayat Melayu untuk Tujuan Pemahaman Komputer. Dewan Bahasa, 27, 65.

Nation, I. S. P. (2001). Learning Vocabulary in Another Language. Cambridge: Cambridge University Press. https://doi.org/10.1017/CBO9781139524759

Omar, A. (1996). Metaphors of Anatomy as a Refelection of Malay Cultural Belief. Jurnal Bahasa Jendela Alam, $1,7-29$.

Omar, A. (2008). Bahasa Melayu di Samudera. Kuala Lumpur: Dewan Bahasa dan Pustaka.

Omar, A. (Ed.). (2015). Ensaiklopedia Bahasa Melayu. Kuala Lumpur: Dewan Bahasa dan Pustaka.

Ramlan, M. N. (1999). Ekologi Asas dan Alam Semulajadi Terpilih. Shah Alam: Universiti Teknologi MARA.

Yunus, K., Mohamed, M., \& Waelateh, B. (2016). The Breadth of Receptive Vocabulary Knowledge among English Major University Students. Journal of Nusantara Studies, 1(1), 7-17.

\section{Copyrights}

Copyright for this article is retained by the author(s), with first publication rights granted to the journal.

This is an open-access article distributed under the terms and conditions of the Creative Commons Attribution license (http://creativecommons.org/licenses/by/4.0/). 